\title{
Investigating the effects of different levels of CRM investment on development of brand equity
}

\author{
Hamed Abbasi ${ }^{a}$, Hamid Reza Abbasi ${ }^{\mathrm{b}}$, Mahsan Hajirasouliha ${ }^{\mathrm{c}}$ and Ashkan Faraji ${ }^{\mathrm{c}}$
}

${ }^{a}$ Department of Management, Tehran Central Branch, Islamic Azad University, Central, Iran

${ }^{b}$ Department of Management, Abhar Branch, Islamic Azad University, Abhar, Iran

${ }^{c}$ Department of Management and Accounting, South Tehran Branch, Islamic Azad University, Tehran, Iran

\author{
CHRON I C L E

\begin{tabular}{l}
\hline Article history: \\
Received July 28, 2013 \\
Accepted 14 January 2014 \\
Available online \\
February 272014 \\
\hline Keywords: \\
CRM \\
Brand equity \\
Proactive marketing \\
Reactive marketing \\
Accountable marketing
\end{tabular}
\begin{abstract}
A B S T R A C T
This paper investigates the effects of different marketing strategies including basic marketing, reactive marketing, accountable marketing, proactive marketing and partnership marketing on brand equity. The proposed study uses two questionnaires, one for measuring the effects of different marketing strategies and the other for brand equity in Likert scale. Cronbach alphas for brand equity and marketing strategies are calculated as 0.71 and 0.86 , respectively. The study has been implemented among 385 regular customers of a Picnic Gas distributer in city of Karaj, Iran. Using Spearman correlation ratio as well as stepwise regression analysis, the study has detected that there were positive and meaningful relationship between marketing strategies and brand equity.
\end{abstract}

\section{Introduction}

These days, we see a tremendous change on the world of marketing in the world and firms have increased the cost of marketing, significantly (Krishnan, 1996). A marketing strategy may consist of five major activities including basic marketing, reactive marketing, accountable marketing, proactive marketing and partnership marketing. Basic marketing consists of various activities applied to get our potential customer's attention. Reactive marketing is the most popular used approach in marketing, which is based on the concept of react. Accountable marketing is based on the concept that all the targeted marketing communications ought to be accounted for in terms of the result or output they create. In other words, every act of communication must focus on a unique selling or an advantage driven point associated with the product, which ultimately results in motivating the customer and contributing on to the brand image of a brand. Proactive marketing is an innovative form of marketing based on new ideas in terms of the creative content implemented as well as the creativity involved in the formation of marketing strategies. It definitely involves significant amount of work but the end result could be much better than other forms of marketing. The customer is normally

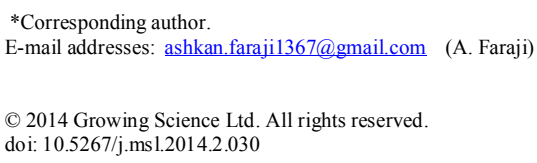


looking for something more than what the actual advantages of a product could be. Therefore, partnership marketing plays essential role on creating marketing communication and propositions for the customer, which includes value addition of advantages to customer. Partnership marketing aims at adding more and more value to the advantages derived by a customer.

Cropanzano et al. (2004) explored the issue of corporate accountability for social injustice by dividing the discussion into three major components. First, they explained the current understanding of large organizations manifested in the prevailing legal and cultural climate and argued that organizations were treated as a kind of juristic person. They also reviewed the psychological processes by which individuals come to attribute responsibility and recommended that there were three central issues to consider when attributing responsibility to organizations for unjust acts. Many firms were held accountable when an alternative state could have been better than a current situation.

Brand equity is another component of building value added business units and brand equity consists of four dimensions including awareness, image, quality and loyalty (van Doorn \& Leeflang, 2014). Kladou and Kehagias (2014) presented a marketing approach towards developing a structural model incorporating a fifth dimension; that of cultural brand assets by building on product and corporate brand equity and the definition of destination branding. They concentrated on cultural urban destinations and reported that the five dimensions are interrelated and important for the customers' evaluation of a cultural destination. Bianchi et al. (2014) performed an investigation towards three South American destinations in an emerging long haul market using a model of consumer-based brand equity (CBBE). They reported that the CBBE model was a suitable tool to explore consumers' behaviors in the long-haul travel context.

Liao and Cheng (2014) performed an investigation on brand equity and the exacerbating factors of product innovation failure evaluation. Yoo et al. (2000) explored the relationships between some selected marketing mix elements and the creation of brand equity. They presented a conceptual framework in which marketing elements were associated with the dimensions of brand equity including perceived quality, brand loyalty, and brand associations combined with brand awareness. These dimensions are then associated with brand equity. The empirical study using a structural equation model supported the research hypotheses and indicated that frequent price promotions, such as price deals, were associated with low brand equity, whereas high advertising spending, high price, good store image, and high distribution intensity were associated with high brand equity.

\section{The proposed study}

This paper investigates the effects of different marketing strategies including basic marketing, reactive marketing, accountable marketing, proactive marketing and partnership marketing on brand equity. The proposed study uses two questionnaires, one for measuring the effects of different marketing strategies and the other for brand equity in Likert scale. Cronbach alphas for brand equity and marketing strategies are calculated as 0.71 and 0.86 , respectively. The study has been accomplished among regular users of some Picnic Gas company located in city of Karaj, Iran. The sample size is calculated as follows,

$N=Z_{\alpha / 2}^{2} \frac{p \times q}{e^{2}}$,

where $N$ is the sample size, $p=1-q$ represents the probability, $z_{\alpha / 2}$ is CDF of normal distribution and finally $\varepsilon$ is the error term. For our study we assume $p=0.5, z_{\alpha / 2}=1.96$ and $e=0.05$, the number of sample size is calculated as $N=384$. The study has distrbuted 385 questionnaires among some randomly selected people who use this product, regularly. The study considers the following five hypotheses,

1. There is a relationship between basic marketing and brand equity. 
2. There is a relationship between reactive marketing and brand equity.

3. There is a relationship between accountable marketing and brand equity.

4. There is a relationship between proactive marketing and brand equity.

5. There is a relationship between partnership marketing and brand equity.

Fig. 1 shows details of the relationship between various marketing components and brand equity.

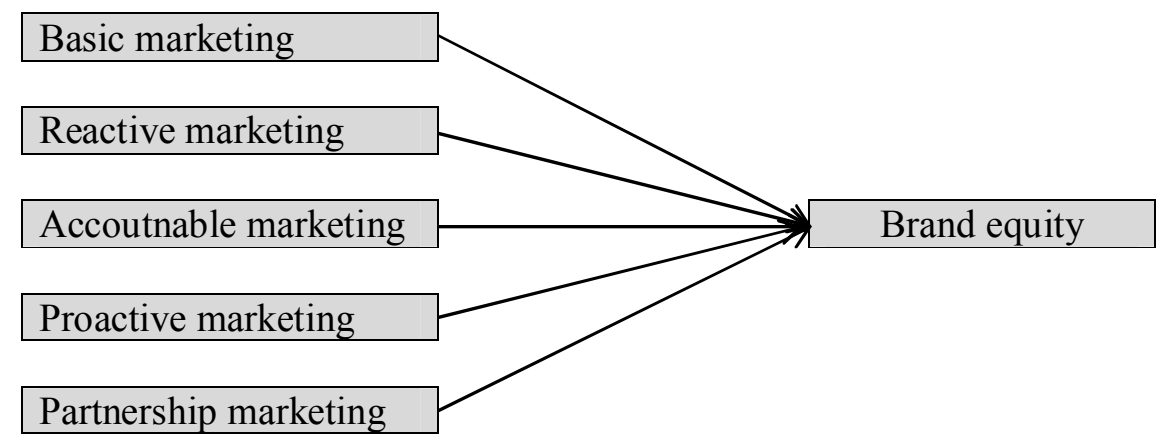

Fig. 1. The proposed study

\subsection{Personal characteristics of the participants}

In our survey, $73.19 \%$ of the participants were male and $26.81 \%$ of them were female. Fig. 2 shows their educational background as well as years of job experiences.

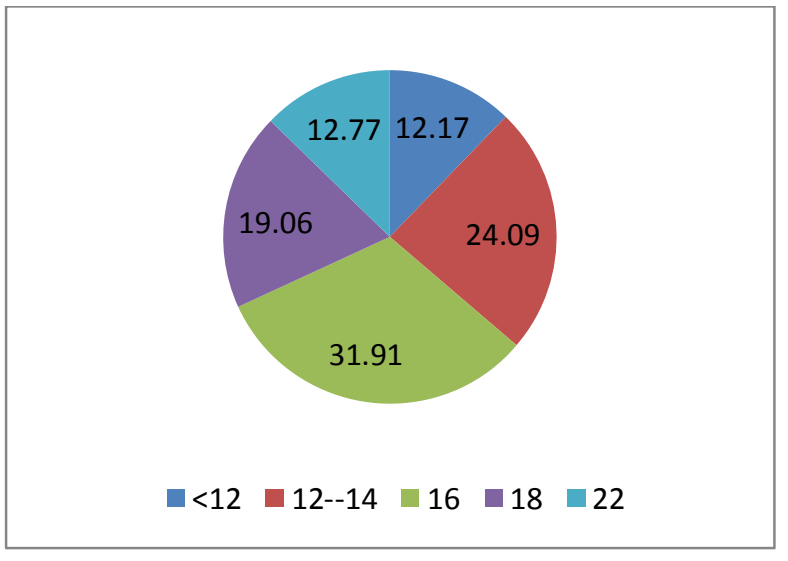

Years of education

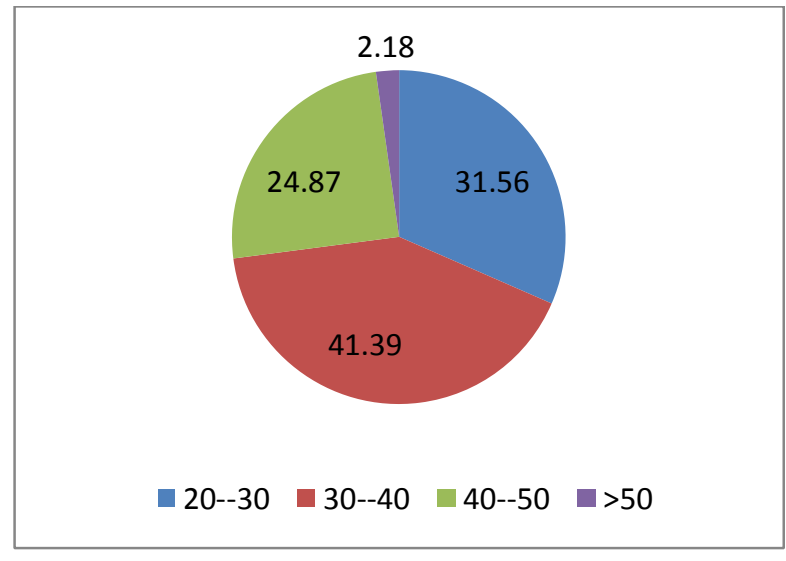

Age

Fig. 2. Personal characteristics of the participants

As we can observe from Fig. 2, most participants in our survey have some educational backgrounds and they are mostly middle-aged people. The implementation of Kolmogorov-Smirnove test implies the data are not normally distributed. Therefore, we use Spearman correlation ratio as well as Stepwise regression test to verify the hypotheses of the survey.

\section{The results}

In this section, we present details of our findings on testing various hypotheses of the survey. Table 1 shows details of the results of Spearman correlation ratio on testing the effects of different marketing strategies on brand equity. 


\section{Table 1}

The results of testing the effect of marketing strategies on brand equity using Spearman correlation

\begin{tabular}{llccc}
\hline Hypothesis & Relationship & r & Sig. & Result \\
\hline First & Basic marketing $\rightarrow$ Brand equity & 0.113 & 0.000 & Confirmed \\
Second & Reactive marketing $\rightarrow$ Brand equity & 0.157 & 0.004 & Confirmed \\
Third & Accountable marketing $\rightarrow$ Brand equity & 0.429 & 0.000 & Confirmed \\
Fourth & Proactive marketing $\rightarrow$ Brand equity & 0.408 & 0.000 & Confirmed \\
Fifth & Partnership marketing $\rightarrow$ Brand equity & 0.362 & 0.000 & Confirmed \\
\hline
\end{tabular}

The results of Table 1 clearly specify that there were positive and meaningful relationship between different components of marketing strategies and brand equity when the level of significance is one percent. The highest correlation is between accountable marketing and brand equity $(\mathrm{r}=0.429$, Sig. $=0.000)$ followed by the relationship between proactive marketing and brand equity $(\mathrm{r}=0.408$, Sig. $=$ $0.000)$ and between partnership marketing and brand equity $(\mathrm{r}=0.362$, Sig. $=0.000)$. We have also performed stepwise regression analysis and Table 2 shows the results of the survey.

Table 2

The summary of stepwise regression analysis

\begin{tabular}{lccccc}
\hline Variable & Coefficient & Standard error & Standard coefficient & t-value & P-value \\
\hline Intercept & 44.867 & 3.620 & & 11.492 & .000 \\
Accountable marketing & 0.541 & 0.293 & 0.374 & 2.715 & .018 \\
Partnership marketing & 0.474 & 0.257 & 0.328 & 2.541 & .000 \\
Reactive marketing & 0.297 & 0.231 & 0.304 & 2.196 & .001 \\
\hline
\end{tabular}

As we can observe from the results of Table 2, three marketing strategies including accountable, partnership as well as reactive marketing influence positively on brand equity $(\alpha=0.01)$.

\section{Conclusion}

In this paper, we have presented an empirical investigation to study the effects of different marketing strategies on brand equity for a Picnic Gas provider in Iran. Using two questionnaires in Likert scale, the study has detected that there were positive and meaningful relationships between various components of marketing planning and brand equity.

\section{References}

Bianchi, C., Pike, S., Lings, I. (2014). Investigating attitudes towards three South American destinations in an emerging long haul market using a model of consumer-based brand equity (CBBE). Tourism Management, 42, 215-223.

Cropanzano, R., Chrobot-Mason, D., Rupp, D. E., \& Prehar, C. A. (2004). Accountability for corporate injustice. Human Resource Management Review, 14(1), 107-133.

van Doorn, J., \& Leeflang, P. S. (2014). Does the importance of value, brand and relationship equity for customer loyalty differ between Eastern and Western cultures?. International Business Review, 23(1), 284-292.

Krishnan, H. S. (1996). Characteristics of memory associations: A consumer-based brand equity perspective. International Journal of research in Marketing,13(4), 389-405.

Kladou, S., \& Kehagias, J. (2014). Assessing destination brand equity: An integrated approach. Journal of Destination Marketing \& Management, 3(1), 2-10.

Liao, S., \& Cheng, C.C.J. (2014). Brand equity and the exacerbating factors of product innovation failure evaluations: A communication effect perspective. Journal of Business Research, 67(1), 2919-2925.

Yoo, B., Donthu, N., \& Lee, S. (2000). An examination of selected marketing mix elements and brand equity. Journal of the Academy of Marketing Science, 28(2), 195-211. 